\title{
Heat Budget in the Ice Cover of the Southern Okhotsk Sea
}

\author{
Derived from In-situ Observations
}

\author{
By Takenobu Toyota, Toshiyuki Kawamura, and Masaaki Wakatsuchi \\ Institute of Low Temperature Science, Hokkaido University, Sapporo, Japan
}

(Manuscript received 2 August 1999, in revised form 12 June 2000)

\begin{abstract}
From in-situ meteorological and ice observation in early February of 1996 and 1997, we estimate the heat budget in the ice cover of the southern Okhotsk Sea. Ice concentration and ice thickness distribution required for its calculation are obtained quantitatively from video analysis. One dimensionalthermodynamical model is used to calculate heat flux. The total heat flux is obtained by summing up the areally weighted heat flux on each ice thickness. As a result, the following characteristics are found in this region. (1) Due to relatively thin ice thickness, turbulent heat flux (sensible + latent) is upward, showing that the sea ice region gives turbulent heat to atmosphere. (2) Thin ice and open area contribute significantly to the total turbulent heat flux over the whole area. (3) Thermodynamical ice growth is limited to below $1 \mathrm{~cm}$ per day on average. The first and third results are the characteristics of this area located at a relatively low latitude, while the second one is generally observed for polar regions. The results also suggest that surface melting occur at daytime mainly due to solar radiation. The salinity of sea ice samples shows the values lower than that of the first-year ice in the polar regions and rather similar to that of the multi-year ice, which is lowered by surface melting during summer; this may support this suggestion.
\end{abstract}

\section{Introduction}

In winter, a strong northwesterly monsoon from Siberia prevails over the southern Okhotsk Sea. This region is located on one of the main cyclone tracks in winter over East Asia (Chen et al. 1991), and is subject to developing cyclones (Nakamura et al. 1986; Gyakum et al. 1989). Since strong horizontal temperature gradient exists between cold continent $\left(T \leq-20^{\circ} \mathrm{C}\right)$ and warm northern Pacific $\left(T \geq 0^{\circ} \mathrm{C}\right)$, it may be possible that heat exchange between the atmosphere and the sea ice area over this region has a significant effect on the cyclone activities there. The possibility that the presence of sea ice in the Okhotsk Sea influences the atmospheric circulation through thermodynamical process has been pointed out mainly from numerical studies. For example, Honda et al. (1996) showed, using the general circulation model, that sea ice area has an effect on a global scale atmospheric circulation through the propagation of wave activities. For a local scale, Sasaki and Deguchi (1988) showed that the sea ice

Corresponding author: Takenobu Toyota, Institute of Low Temperature Science, Hokkaido University, Nishi 8, Kita 19, Kita-ku, Sapporo 060-0819, Japan. E-mail: toyota@lowtem.hokudai.ac.jp

(C)2000, Meteorological Society of Japan area can affect the convergent band off the western Hokkaido coast in winter, and Okubo and Mannoji (1994) showed that the sea ice area can affect the wind pattern in Hokkaido. However, because of the lack of in-situ observational data, it is still unknown how the sea ice area affects the heat budget in the Okhotsk Sea. Recently, Tachibana et al. (1996) have reported the abrupt decrease of the sea ice cover by about two thirds over the southern region of the Okhotsk Sea after 1989. In order to discuss its effect on the atmosphere, a quantitative estimation of the heat budget on the basis of observation should be required.

Besides, this region is also an important area to ocean circulation. The dense water produced by ice formation can affect the ocean structure. This region has recently been pointed out as a possible origin of North Pacific Intermediate Water (Watanabe and Wakatsuchi 1998), and hence it is important to estimate how much sea ice can be produced in this area. This estimation of the growth amount of sea ice also serves to understand ice growth processes in this region.

Thus the southern region of the Okhotsk Sea (around $45^{\circ} \mathrm{N}$ ) is an important area for both the atmospheric and oceanic circulation. In early Febru- 
ary of 1996 and 1997, we carried out ice observations in this region, using an ice breaker, $S O Y A$. The major purpose of this paper is to discuss the characteristics of sea ice area in this region on the basis of this in-situ observational data from the viewpoint of heat exchange, which can affect the sea ice structure. For this purpose, we calculate the heat budgets from meteorological and ice observation data, estimate turbulent heat flux from ocean to atmosphere and ice growth rate, and examine the feature of sea ice samples which were taken during the cruise. In this calculation, the sea ice albedos, which were estimated from the observation during this cruise, are used (Toyota et al. 1999). According to Maykut (1978), heat budget in a relatively thin sea ice region largely depends on ice thickness. In the southern Okhotsk Sea where a relatively thin ice is dominant, therefore, ice distribution data is required. We measured ice concentration and ice thickness distribution with the video monitoring system during the cruise. We focus on the general feature here.

In polar regions, lots of observations on heat budget have been done so far, especially for a relatively thick ice. On the other hand, in the marginal ice zones where young ice dominates, there are few observations for the heat budget, except for some Antarctic regions. Although Andreas and Makshtas (1985) carried out the detailed heat budget observation over the Antarctic Ocean, ice observations were not included. Therefore, our observation seems to be one of the first trials of ice observations in connection with meteorological and hydrographical observation in the marginal ice zones. Considering the fact that the marginal ice zones interact greatly with the atmospheric circulation (e.g., Walsh and Johnson 1979; Overland and Pease 1982), it is important to investigate heat budget properties from in-situ observation. Therefore, we believe that our observational study in the southern Okhotsk Sea also serves to understand the characteristics of sea ice in the marginal ice zone.

This paper is organized as follows. In the next section, the meteorological and ice conditions are described with their measurements. In Section 3, we will explain the method of heat budget calculation. The results will be shown in Section 4. We will summarize and discuss them in Section 5.

\section{Meteorological and ice observations}

During the period of 3 to 5 February of 1996 and 2 to 9 February of 1997 , we carried out in-situ observations aboard an ice breaker $S O Y A$ in the southern region of the Okhotsk Sea (Fig. 1) as one of collaborative observations with the Japan Coast Guard. In these cruises, we did direct measurements of both meteorological and ice conditions, in particular ice concentration and thickness. In addition, we collected sea ice samples to investigate their structure.
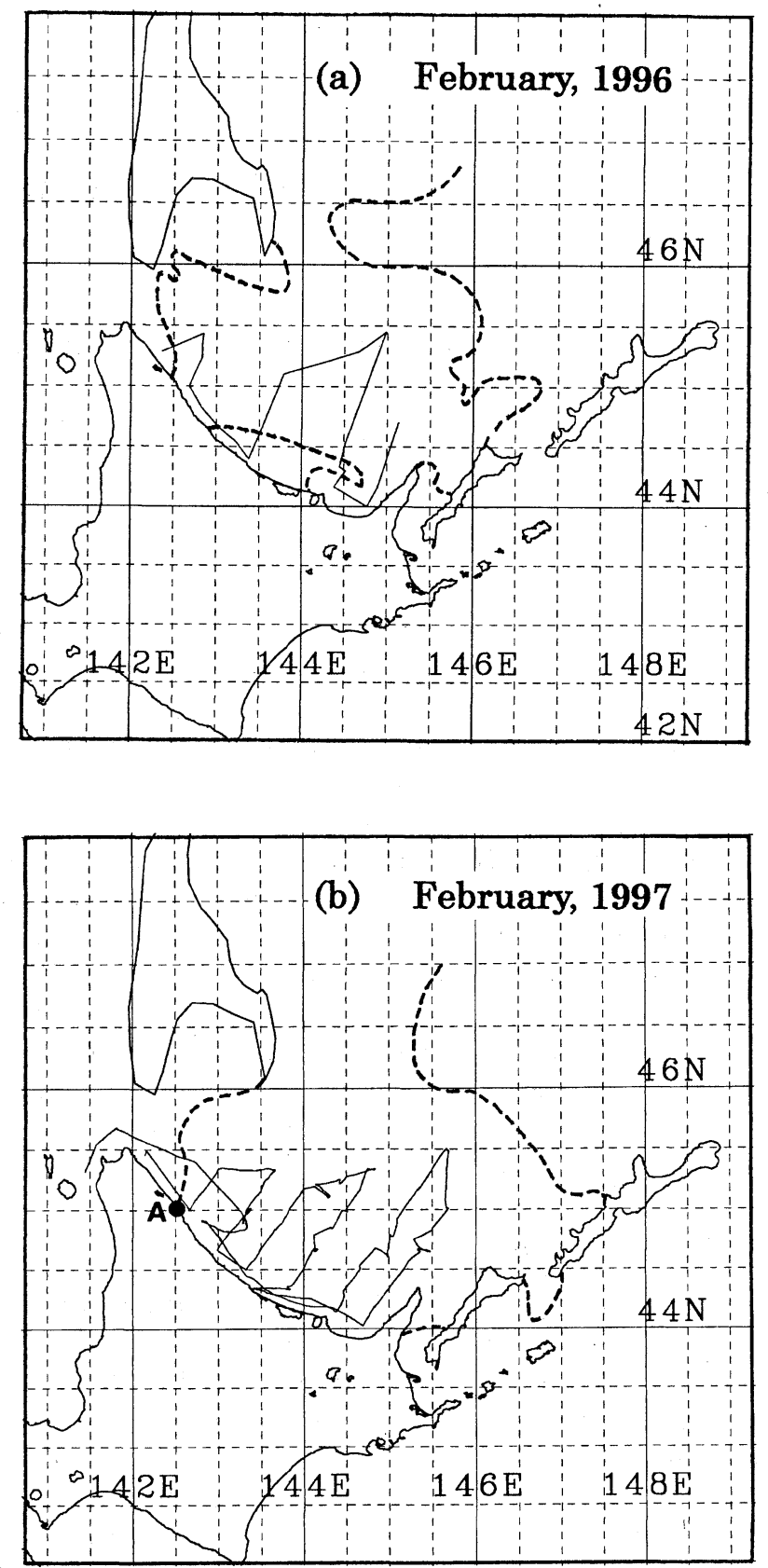

Fig. 1. Geographical map of the southern Okhotsk Sea with the ship tracks (thin lines) and ice edges (thick broken line) for (a) 1996 and (b) 1997. Black point A denotes the ECMWF grid point which is used for verification of heat budget calculation.

\subsection{Ice conditions}

During the observational period for 1996, the weather was relatively calm with mostly clear to cloudy sky and neither snowstorm nor big swells. The air temperature ranged from -6 to $-1^{\circ} \mathrm{C}$, and the wind speed was 4 to $10 \mathrm{~m} / \mathrm{s}$, changing from northwestern to northeastern direction. In 1997, the weather was also relatively calm. The air temperature ranged from -10 to $-2^{\circ} \mathrm{C}$, and the wind speed 
was 1 to $10 \mathrm{~m} / \mathrm{s}$. Neither snowstorm nor big swells occurred during the observation period.

In 1996, the sea ice extent in the Okhotsk Sea was record-breakingly small until early February. The sea ice extent in the southern region of the Okhotsk Sea was also below normal until late January, while it spread nearly to the normal in early February. In 1997, sea ice extended almost normally from January to February in the southern region of the Okhotsk Sea.

\subsection{Measurements of meteorological and ice data}

Air temperature and relative humidity were measured with a thermo-/ hygro-meter with a ventilating motor fan. This instrument was mounted at the ship mast of $15 \mathrm{~m}$ height above the sea level so as to avoid the ship body effect. The data were recorded on a logger at five minute's interval. Upward and downward short wave radiation was measured with two pyranometers at the ship bow. A gimbaling mechanism was used to keep the measuring surface horizontal. The details of short wave radiation measurement are described in Toyota et al. (1999). Anemometers installed at the top of the ship mast, $22 \mathrm{~m}$ above the sea level, were used to get wind data. The absolute wind data were obtained by subtracting the ship speed and direction from the measured values. This observation was conducted by the ship's crew of ' $S O Y A$ ' at hourly intervals and recorded on a log-book in the form of wind force. We used the data for analysis. Cloud amount (in tenths) and weather were observed visually and recorded at hourly intervals during the cruise.

We obtained the data of ice concentration and ice thickness with the video analysis. The details of the analytical method are described in Toyota et al. (1999). Since the ice thickness data are obtained from relatively large area in the southern region of the Okhotsk Sea (see their Fig. 5), we regarded the measured ice thickness histogram as the representative areal ice thickness distribution. The fraction of ice coverage in this region is determined by averaging the ice concentration during the cruise. Relatively thick ice, which was usually covered with snow, can be estimated by this method. On the other hand, thin ice area with no snow cover cannot be analyzed by video analysis because it is difficult to distinguish ice from water on video images. Therefore, the fraction of this area (nilas) is calculated from the results of the visual observation which was conducted at hourly intervals during the cruise. We recorded the areal fraction of each ice type around our ship according to the classification of WMO (1970).

\section{Method of calculation}

A thermodynamic ice model is used to estimate heat budgets and ice production. The model we
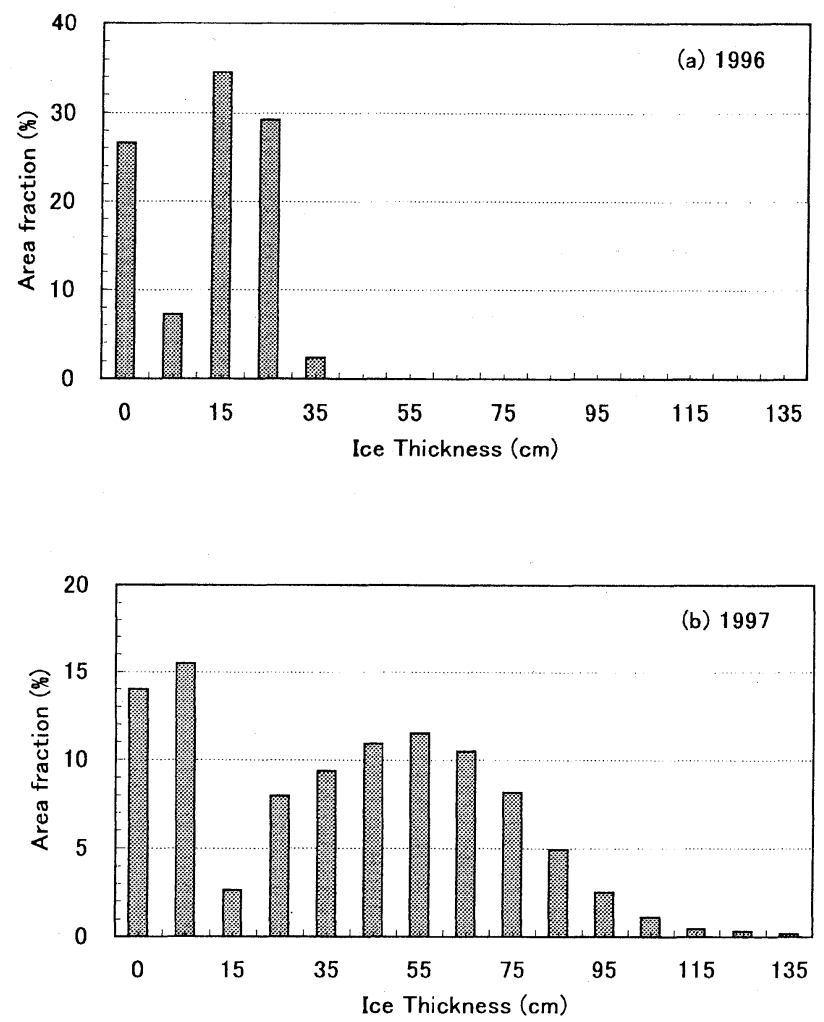

Fig. 2. Areal fraction of ice thickness for (a) 1996 and (b) 1997, used for heat budget calculation. We treat $H_{i}=0$ and $5 \mathrm{~cm}$ as open water and nilas, respectively.

used is similar to those of Maykut (1978 and 1982), which are used to investigate the effects of ice thickness variations on heat exchange over the central Arctic. Although he assumed ice thickness distribution calculated by Thorndike et al. (1975), we use our observational data of it.

\subsection{Ice thickness distribution}

We allocated the areal fraction of ice thickness at $10 \mathrm{~cm}$ intervals $\left(H_{i}=15,25,35,45, \ldots \mathrm{cm}\right)$ among total ice concentration $(66.2 \%$ in $1996,70.5 \%$ in 1997) which was calculated from video analysis. The areal fraction of the thinnest ice $\left(H_{i}=5 \mathrm{~cm}\right)$ was obtained from visual observation of nilas and the remnant was allocated to open water $\left(H_{i}=0 \mathrm{~cm}\right)$. The resultant ice thickness distribution is shown in Fig. 2. The distributions are significantly different between 1996 and 1997. Remarkably thin ice is predominant in 1996, while sea ice is remarkably thick in 1997. Therefore, the results of these two years may give a comparison between significantly different ice thickness conditions for the similar weather.

\subsection{Meteorological data}

In order to grasp the general features of the heat budgets in this region, we use the averaged data during the observation period. For this purpose, we prepare the hourly meteorological data by taking av- 


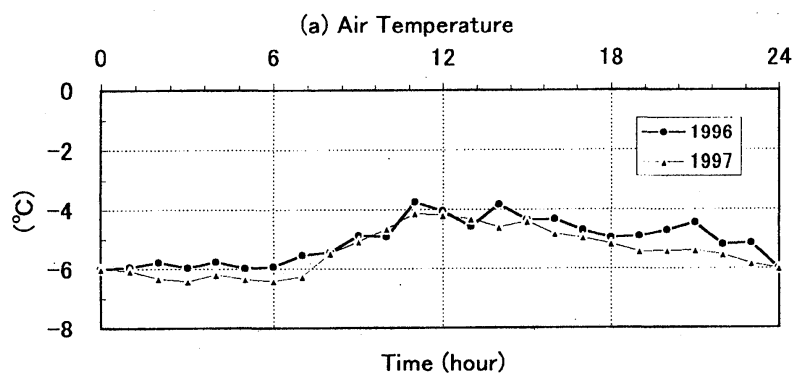

(b) Relative Humidity

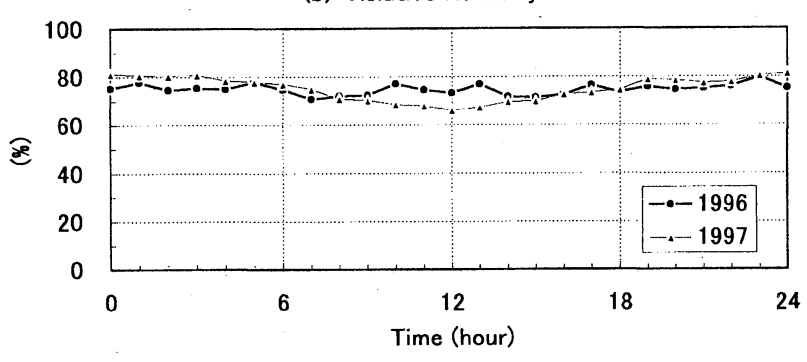

(c) Solar Radiation

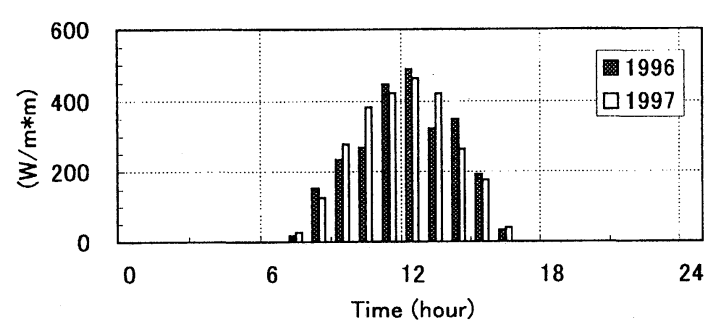

(d) Wind speed

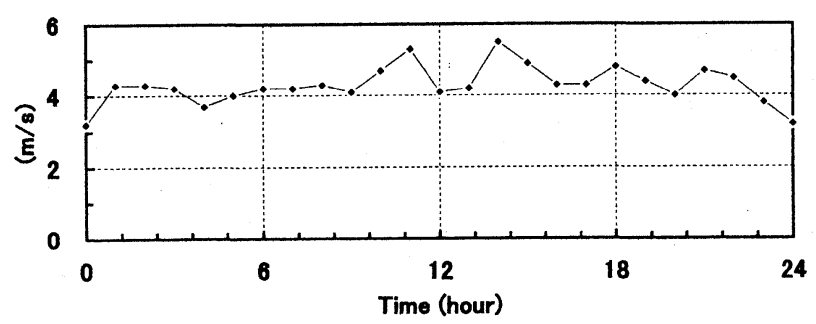

Fig. 3. Averaged diurnal cycle of meteorological data; (a) air temperature, (b) relative humidity, (c) solar radiation and (d) wind speed. Wind speed data are drawn only for 1997 because wind data could be taken only at daytime in 1996.

erages at each hour during the period. The hourly data of air temperature, relative humidity, and solar radiation are shown in Figs. 3a-c. These data are considered to be representative of the diurnal cycle during this period. Daily mean data are given by averaging these data for one day. Those of individual years are listed in Table 1. This table and Fig. 3 shows that meteorological conditions are similar in
Table 1. Daily mean meteorological conditions.

\begin{tabular}{|l||r|r|}
\hline Elements & \multicolumn{1}{|c|}{1996} & \multicolumn{1}{c|}{1997} \\
\hline Air temp. (C) & -5.0 & -5.4 \\
Relative Humidity (\%) & 74.8 & 74.9 \\
Solar radiation $\left(\mathrm{Wm}^{-2}\right)$ & 104.5 & 108.4 \\
\left.${\text { Wind speed }\left(\mathrm{ms}^{-1}\right)}\right)$ & 6.6 & 4.3 \\
Cloud amount $(1 / 10)$ & 7.0 & 6.6 \\
Air Pressure $(\mathrm{hPa})$ & 1013.0 & 1012.9 \\
\hline
\end{tabular}

both years. Since ice conditions are significantly different between the two years, the difference of the resultant heat flux can be considered to be mainly due to the effect of ice thickness distribution on heat budgets.

\subsection{Assumption}

Heat budgets are calculated on the following assumptions:

(1) Vertical heat transport is predominant.

(2) Sensible heat flux $(F S H)$, latent heat flux $(F L H)$, net solar radiation $(F S W)$, net long radiation $(F L W)$, and conductive heat flux in ice $(F C I)$ are balanced at the thin $\Delta H$ layer of sea ice surface. Since mostly sea ice is covered with snow, we here take $\Delta H$ to be $2 \mathrm{~cm}$, considering the fact that the optical extinction coefficients of visible wavelengths range from 60 to $90 \mathrm{~m}^{-1}$ for snow grain sizes of $1 \mathrm{~mm}$ (Mellor 1977).

(3) Areal ice thickness distribution is represented by the frequency of observed ice thickness (Fig. 2).

(4) Sea ice is covered with snow, except for nilas, and snow depth is given by one fifth of ice thickness.

Here, we examine to justify these assumptions below.

Assumption (1) is approximately satisfied because the ice floe size mostly ranged from a few to one hundred meters in our observation area, and was much greater than ice thickness.

The full balance equation of heat flux at the surface is described as follows:

$$
\begin{aligned}
& \rho_{i} \Delta H C_{i} \frac{\partial T_{S}}{\partial t} \\
& =F S H+F L H+F S W+F L W+F C I,
\end{aligned}
$$

where $\rho_{i}, \Delta H, C_{i}$, and $T_{S}$ is ice density, thickness of surface layer, specific heat, and surface temperature, respectively. According to Ono (1967), $C_{i}$ is $1.57 \mathrm{calg}^{-1} \mathrm{~K}^{-1}\left(=6.57 \mathrm{Jg}^{-1} \mathrm{~K}^{-1}\right)$ for ice temperature $=-4^{\circ} \mathrm{C}$ and ice salinity $=4 \mathrm{psu}$. The 
change of the weekly mean air temperature (the observation period is about one week) is below $5^{\circ} \mathrm{C}$ (that is, below $1 \mathrm{deg}$./day). Since the change of surface temperature is similar to that of air temperature, the left term is estimated as below $1.4 \mathrm{~W} / \mathrm{m}^{2}$ if $\Delta H$ is taken to be $2 \mathrm{~cm}$. Therefore, we consider the left term of Eq. (1) is negligible and assumption (2) approximately holds true. If the surface is covered with snow, since the density and specific heat is smaller than those of ice, assumption (2) also holds good.

When the ship selected a thinner ice route, the frequency of the observed ice thickness would be biased to thinner ice and assumption (3) would not be satisfied. But most of the sea ice was below the ability of the ship's ice breaking (about $1 \mathrm{~m}$ ) and she did not seem to take a thinner route. Therefore, we consider that assumption (3) is approximately satisfied.

Since most of the ice floes but nilas were observed to be covered with snow, assumption (4) is also satisfied. The ratio of snow depth and ice thickness was determined by the result of video analysis (Fig. 4). They are well correlated and the ratio (broken line) is about $1 / 5$. (Although uncertainty remains regarding snow thickness, we made sure that our results are insensitive to snow thickness.)

\subsection{Thermodynamic ice growth model}

When the surface temperature $\left(T_{S}\right)$ is below the freezing point in Kelvin, the heat balance equation at the surface can be expressed as:

$$
\begin{aligned}
& F S H\left(T_{S}\right)+F L H\left(T_{S}\right)+ \\
& F S W+F L W\left(T_{S}\right)+F C I\left(T_{S}\right)=0 .
\end{aligned}
$$

Here a flux toward the surface is taken to be positive, and one away from the surface is negative. The sensible heat flux and the latent heat flux is calculated using the bulk method. $F S H$ is obtained from $\rho c_{p} C_{s} u\left(T_{a}-T_{S}\right)$, where $T_{a}$ is the observed air temperature in Kelvin, $\rho$ is the air density $\left(1.3 \mathrm{~kg} / \mathrm{m}^{3}\right)$, $c_{p}$ is the specific heat of the air $(1004 \mathrm{~J} / \mathrm{kg} / \mathrm{K}), C_{s}$ is the transfer coefficient for sensible heat (discussed later), and $u$ is the observed wind speed. $F L H$ is obtained from $0.622 \rho L_{v} C_{e} u\left(r e_{s a}-e_{s S}\right) / p$, where $L_{v}$ is the latent heat of sublimation $\left(2.84 * 10^{6} \mathrm{~J} / \mathrm{kg}\right.$; Yen 1981), $C_{e}$ is the transfer coefficient for latent heat, $r$ is the observed relative humidity, $p$ is the surface pressure, and $e_{s}$ is the saturation vapor pressure. The dependence of $e_{s}$ on air temperature is expressed as a fourth-order polynomial developed by Maykut (1978). Since the ice thickness is relatively thin in this region, we assume that the temperature gradient in the ice is linear, so that the conductive heat flux $(F C I)$ can be written as $\gamma\left(T_{B}-T_{S}\right)$, where $T_{B}$ is the temperature at the ice bottom and is taken to be the freezing temperature $(271.35 \mathrm{~K})$ and $\gamma$ is the thermal conductance of the ice-snow slab (=

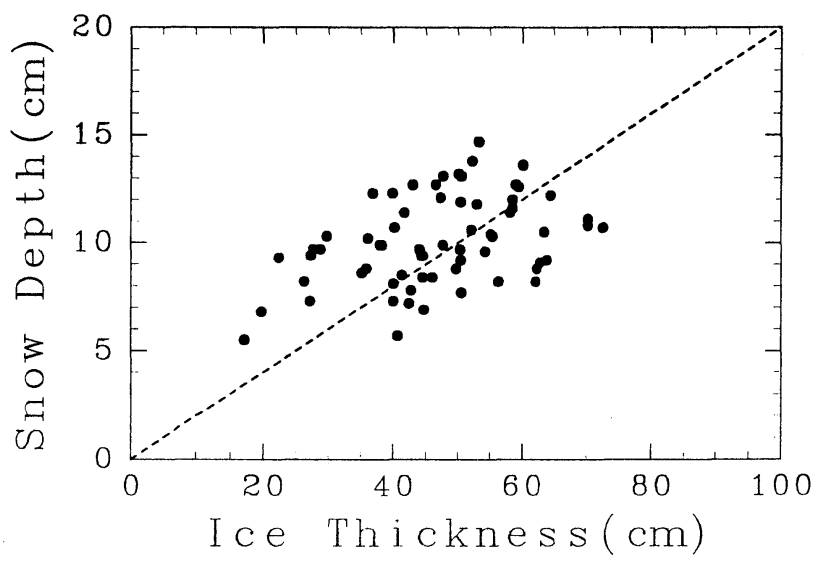

Fig. 4. Correlation between snow depth and ice thickness.

$\left.k_{i} k_{s} /\left(k_{s} H_{i}+k_{i} H_{s}\right)\right)$, where $k$ and $H$ is the thermal conductivity and thickness, respectively, and the suffix $_{i}$ and ${ }_{s}$ denote ice and snow, respectively.

The absorbed short wave radiation $(F S W)$ is described as $F_{r} *(1-\alpha) *\left(1-i_{0}\right)$, where $F_{r}$ is the solar radiation reaching to the ground, $\alpha$ is surface albedo, and $i_{o}$ is the transmittance. As for albedo, 0.07, 0.12, and 064, which were estimated from in-situ observation (Toyota et al. 1999), are used for open water, nilas $\left(H_{i}=5 \mathrm{~cm}\right)$, and thicker ice $\left(H_{i} \geq 15 \mathrm{~cm}\right)$, respectively. Since the extinction coefficient of snow is more than $60 \mathrm{~m}^{-1}$ (Mellor 1977 ), we set $i_{o}=0$ except for nilas $\left(i_{o}=0.18\right.$; Grenfell and Maykut 1977).

The incident long wave radiation $\left(F L W_{1}\right)$ is obtained from $F L W_{1}=0.7855 *\left(1+0.2232 C^{2.75}\right) * \sigma T_{a}^{4}$, where $C$ is cloud amount $(0 \leq C \leq 1)$. This formula was derived from observation under the small vapor pressure (less than $2 \mathrm{hPa}$ ) in the polar region by Maykut and Church (1973). In our case, this formula seems to hold true because the averaged vapor pressure was about $2 \mathrm{hPa}$ during the cruise. The emitted long wave radiation $\left(F L W_{2}\right)$ is described as $F L W_{2}=\varepsilon * \sigma T_{S}^{4}$. Emissivity $\varepsilon$ is taken to be 0.97 for open water and nilas $\left(H_{i}=5 \mathrm{~cm}\right)$ and 0.99 for thicker ice.

After substituting the observed values, the Eq. (2) is resolved for $T_{S}$ using the iterative NewtonRaphson method. Then the individual fluxes are calculated by substituting the obtained $T_{S}$. If $T_{S}$ is greater than the melting point $(273.15 \mathrm{~K})$, we set $273.15 \mathrm{~K}$ as $T_{S}$ and assume that the residual term $(=F S H+F L H+F S W+F L W+F C I)$ is used for melting ice. For open water, $T_{S}$ is taken to be freezing temperature $(271.35 \mathrm{~K})$ and the residual term $(F Q=F S H+F L H+F S W+F L W+F C I)$ is calculated. If this term is negative, ice will be newly produced.

On the other hand, the heat balance equation at the ice bottom is expressed as: 


$$
\rho_{i} L_{f} \frac{d H_{i}}{d t}=F C I-F_{w},
$$

where $\rho_{i}$ is the ice density $\left(900 \mathrm{~kg} / \mathrm{m}^{3}\right), L_{f}$ is the latent heat of fusion (discussed later), and $F_{w}$ is the ocean heat flux. If we set $F_{w}$ to be zero, the growth rate of ice thickness can be calculated as $F C I / \rho_{i} L_{f}$ from the Eq. (3). For open water, the ice growth rate is calculated as $-F Q / \rho_{i} L_{f}$. The heat fluxes and ice growth rate of total area are obtained by summing up the area-weighted values of individual ice thicknesses.

\subsection{Physical parameters}

Prior to analysis, we discuss three essential physical parameters which are used in the model. The first one is the heat transfer coefficient. This parameter is taken to be $1.37 * 10^{-3}$ for both sensible heat flux and latent heat flux after Andreas and Makshtas (1985) because their observation conditions were quite similar to ours. Both are shipbased observations and the measurement heights of wind speed and air temperature are almost the same $\left(21 \mathrm{~m}[u]\right.$ and $11 \mathrm{~m}\left[T_{a}\right]$ in their case, and $22 \mathrm{~m}[u]$ and $15 \mathrm{~m}\left[T_{a}\right]$ in our case), and the usefulness of the coefficient value was checked through the detailed profile measurements by them. On the other hand, somewhat smaller values are expected for open water and nilas because roughness is much less than thicker ice. Here we used the value of $1.0 * 10^{-3}$ which was obtained from the measurements off the Hokkaido coast by Aota et al. (1989).

The second one is latent heat of fusion. In general, latent heat of fusion of sea ice can be expressed as follows:

$$
\begin{aligned}
& L_{f}=4.19 * 10^{3} * \\
& {\left[79.68-0.505\left(T_{i}-273.15\right)-0.0273 S_{i}+\frac{4.3115 * S_{i}}{T_{i}-273.15}\right]} \\
& \mathrm{J} / \mathrm{kg} \quad(\text { Yen 1981), }
\end{aligned}
$$

where ice temperature $T_{i}$ is set to be the freezing temperature $(271.35 \mathrm{~K})$. Ice salinity $S_{i}$ is determined from ice sample data. We collected 14 and 35 ice samples during the cruises in 1996 and 1997, respectively. After the cruises, we investigated their ice structures through thin section analysis and measured ice salinity and density. It is known that ice salinity decreases with the increase of ice thickness due to desalinization. Bulk ice salinity of our samples is plotted as a function of ice thickness in Fig. 5. This figure shows that $S_{i}$ decreases with ice thickness for $H_{i} \leq 15 \mathrm{~cm}$, while $S_{i}$ is almost constant for $H_{i} \geq 15 \mathrm{~cm}$. From the estimated regression line, $S_{i}$ is taken to be 9.1 psu for open water $\left(H_{i}=0 \mathrm{~cm}\right)$ and $7.0 \mathrm{psu}$ for $H_{i}=5 \mathrm{~cm}$. For thicker ice $\left(H_{i} \geq 15 \mathrm{~cm}\right)$, the averaged constant value (3.5 psu) is given in this calculation.

Finally, thermal conductivity is taken to be $0.3 \mathrm{Wm}^{-1} \mathrm{~K}^{-1}$ for snow layer and $2.0 \mathrm{Wm}^{-1} \mathrm{~K}^{-1}$

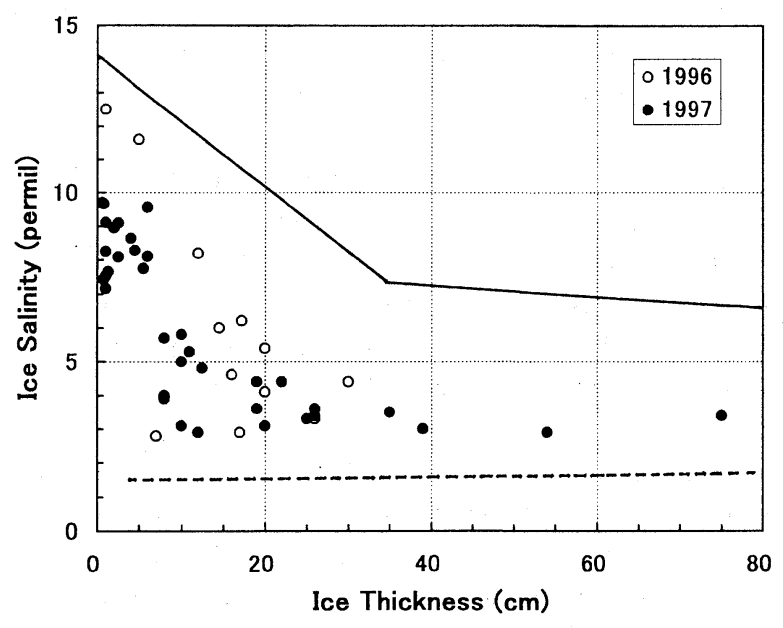

Fig. 5. Bulk salinity of sampled ice as a function of ice thickness. Solid line shows the ice salinity of the first-year ice in the polar regions, and broken line shows that of muti-year ice; both data were compiled by Cox and Weeks (1974).

for ice. In general, the thermal conductivity of snow can be represented as $k_{s}=2.22362 * \rho_{s}^{1.885}$ (Yen 1981). When $\rho_{s}$ is about $0.35 \mathrm{~g} / \mathrm{cm}^{3}, k_{s}$ is estimated as 0.3 . The thermal conductivity of sea ice is expressed as $k_{i}=k_{0}\left(T_{i}\right)+\frac{0.13 S_{i}}{T_{i}-273.15}$ (Untersteiner 1961 ), where $k_{0}$ is thermal conductivity of pure ice, and $S_{i}$ is ice salinity. This formula gives an almost constant value of $2.0 \mathrm{Wm}^{-1} \mathrm{~K}^{-1}$ under the conditions of this ice area.

\section{Results}

\subsection{Daily mean}

Here we used the daily mean meteorological data obtained from averaged hourly data. The result is shown in Fig. 6. In this case, the surface temperature of sea ice is minus for all ice thickness and thus $F Q$, a residual term $(=F S H+F L H+F C I+$ $F S W+F L W)$ appears only for open water as mentioned previously. If $F Q \leq 0$, ice forms by the thickness of $\left(-F Q /\left(\rho_{i} L_{f}\right)\right)$ at open ocean surface. It is remarkable in these figures that the contribution of solar radiation is prominent in both years compared with that of the other fluxes. This result is in contrast with that over thin ice area in the polar region (Maykut 1978), where the sensible heat flux dominates the heat exchange with the atmosphere, and seems to be one of the features of sea ice at a low latitude. The estimated turbulent heat flux, $28.7 \pm 1.4 \mathrm{~W} / \mathrm{m}^{2}$ (FSH: $6.2 \mathrm{~W} / \mathrm{m}^{2}$, $\left.F L H: 22.4 \mathrm{~W} / \mathrm{m}^{2}\right)$ in 1996 and $16.2 \pm 1.5 \mathrm{~W} / \mathrm{m}^{2}$ $\left(F S H=2.5 \mathrm{~W} / \mathrm{m}^{2}, F L H=13.7 \mathrm{~W} / \mathrm{m}^{2}\right)$ in 1997 , is nearly the same as that estimated in the Antarctic pack ice region at the beginning of the melting season $\left(0 \sim 60 \mathrm{~W} / \mathrm{m}^{2}\right.$; Andreas and Makshtas 1985). But the result is a little different from theirs in that 

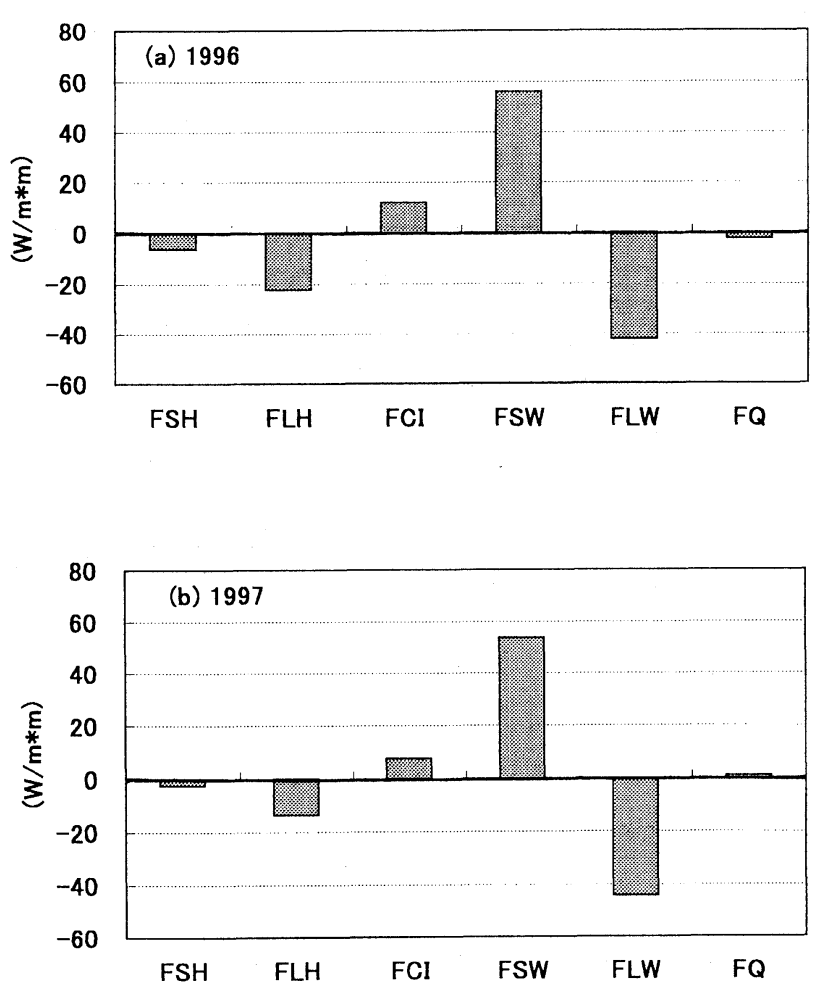

Fig. 6. Daily mean area-averaged heat budgets over the entire sea ice area. FSH: sensible heat flux. FLH: latent heat flux. FCI: conductive heat flux in ice. FSW: solar radiation. FLW: long wave radiation. FQ: residual.

the latent heat flux is greater than the sensible heat flux. This difference is mainly attributed to relatively high air temperature. Here, the error values are determined by the $95 \%$ confidence interval of albedo $( \pm 0.03)$, because solar incidence is expected to be a leading factor of the heat budget in this region. The contribution of conductive heat flux is also small, so that the ice growth rate is limited to $0.49 \pm 0.01 \mathrm{~cm} /$ day in 1996 and $0.25 \pm 0.01 \mathrm{~cm} /$ day in 1997. About half of the ice growth is produced within thin ice layers of 5 and $15 \mathrm{~cm}$. Since ice conditions have a remarkable contrast between two years as mentioned earlier, these values seem to give nearly maximum and minimum under similar meteorological conditions. Thus, the averaged ice growth rate is limited and thermodynamic growth is small in this region.

Next, it is noted that the turbulent flux of the total area is upward, as shown in Fig. 6, whereas it is downward in the polar region because thick ice area is dominant (Maykut 1982). This implies that the sea ice area in this region works as a heating source for the atmosphere rather than a cooling source. To further examine this feature, the turbulent fluxes for each ice thickness are presented in Fig. 7. It is shown that the turbulent flux decreases signif-

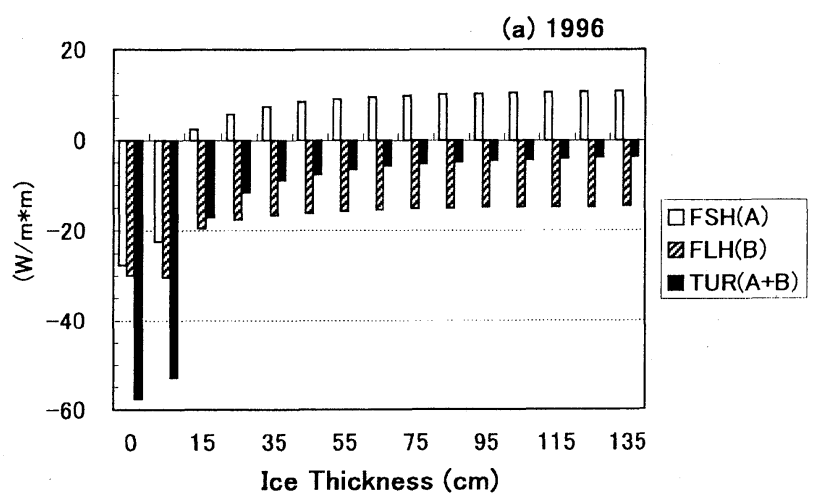

(b) 1997

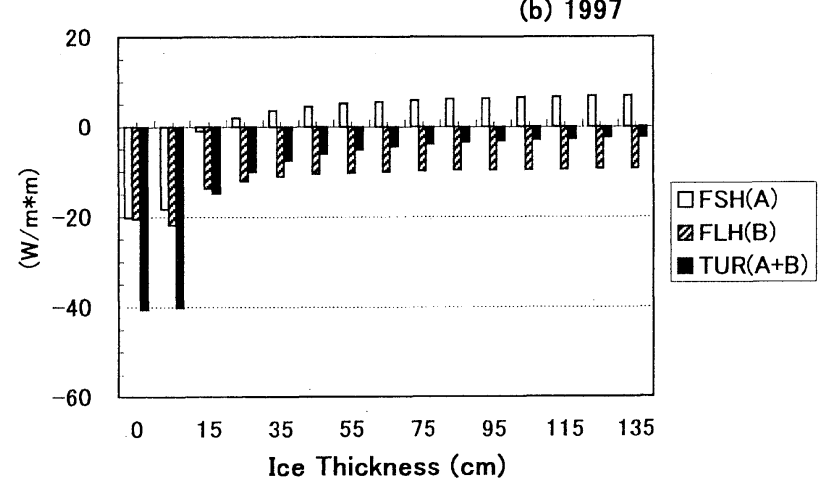

Fig. 7. Daily mean turbulent heat flux as a function of ice thickness. Positive FSH means that the surface temperature of sea ice is greater than that of air temperature.

icantly with ice thickness especially below $50 \mathrm{~cm}$ thickness. This decrease is attributed mostly to the change of the sensible heat flux. With the increase of ice thickness, the surface temperature becomes less influenced by the underlying relatively high ocean temperature. Thus the surface temperature gets closer to the air temperature and the upward sensible heat flux decreases. Finally, the sensible heat flux becomes downward, like the polar region, for more than $25 \mathrm{~cm}$ ice thickness. In this region, however, since relatively thin ice area is dominant, the total turbulent flux becomes upward (see Fig. 8). It is noticeable in this figure that more than half of the total upward turbulent heat flux is owed to open water and nilas area in both years. Thus open water and thin ice area characterizes the heat budgets in this region. Figure 7 also shows that without sea ice the turbulent heat flux would increase to $57.6 \mathrm{~W} / \mathrm{m}^{2}$ in 1996 and $40.6 \mathrm{~W} / \mathrm{m}^{2}$ in 1997 (refer to open area). These values are twice the area-averaged values. This implies that the turbulent heat flux is reduced by half due to partly covered sea ice.

\section{2 $E C M W F$ data}

So far we have discussed the heat budgets during our limited observation period. Here, we ex- 

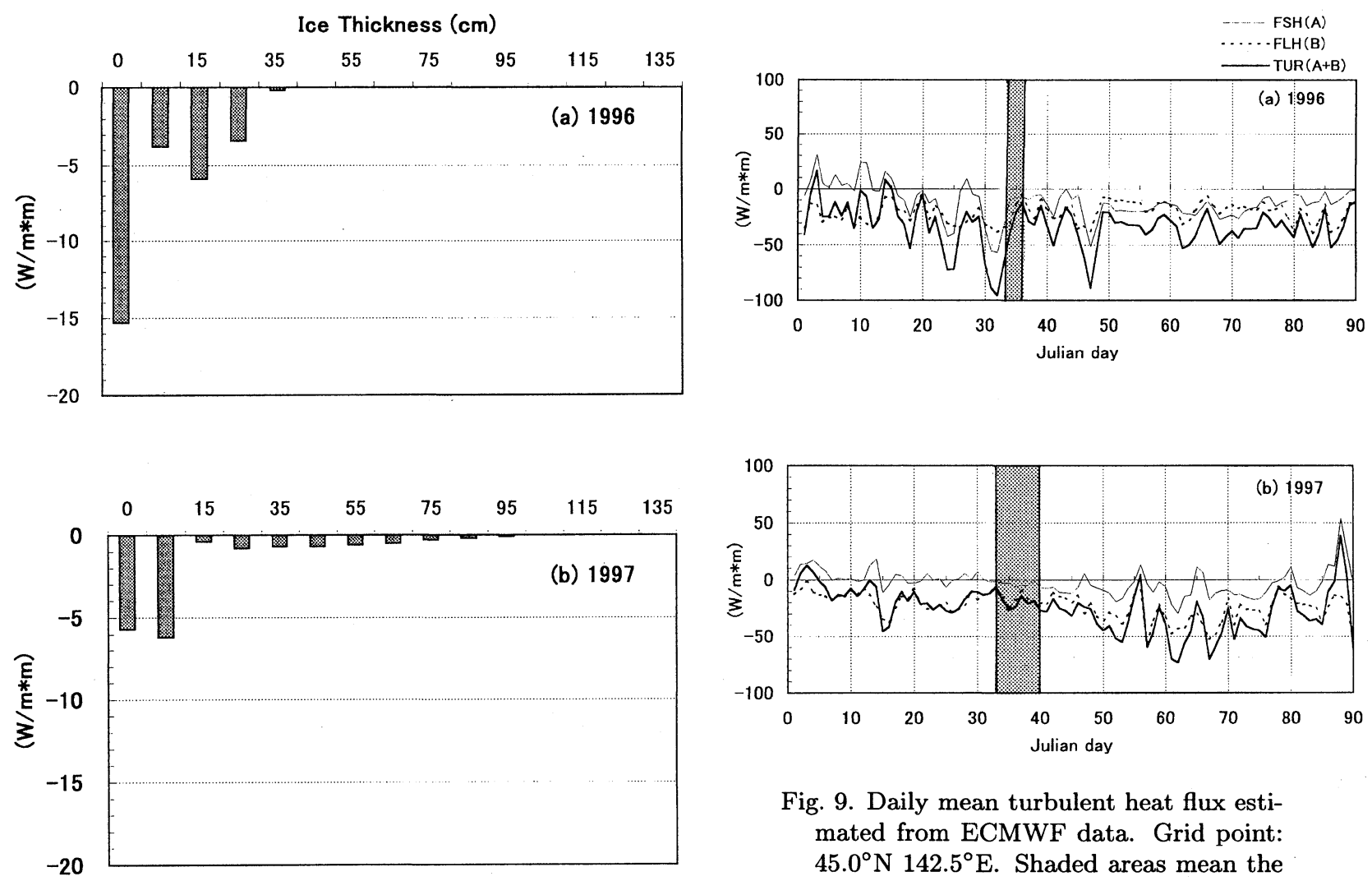

Fig. 8. Area-weighted daily mean turbulent heat flux $(\mathrm{FSH}+\mathrm{FLH})$ as a function of ice thickness for (a) 1996 and (b) 1997.

amine whether the above results hold good for the other cold periods, using an ECMWF twice daily grid data near Hokkaido coast $\left(45.0^{\circ} \mathrm{N}, 142.5^{\circ} \mathrm{E}\right.$, refer to Fig. 1). We assume that the ice conditions (concentration and thickness) are the same as those during the observation period. Since ice thickness data were taken at an early stage of sea ice season, the results of turbulent flux and ice growth rate may give the upper limits of real fields. The method of calculation is same as the above except that heat transfer coefficient is taken to be slightly larger values of $1.40 * 10^{-3}$ (Persson et al. 1997), taking into account that the surface wind height is $10 \mathrm{~m}$ in ECMWF data. The daily averaged air temperature, wind speed, and dew point temperature are used. The cloud amount is assumed to be 0.7 here on the basis of our observation. As for daily solar radiation $\left(Q_{s}\right)$, the following formula developed for the ocean adjacent to Japan by Kim (1992) is applied here.

$I_{0}=A_{0}+A_{1} \cos \phi+B_{1} \sin \phi+A_{2} \cos 2 \phi+B_{2} \sin 2 \phi$

$Q_{s 0}=I_{0}\left(0.865-0.5 C^{2}\right)\left(1-\alpha_{s}\right)$,

where $\phi$ is equal to $(\mathrm{t}-21) * \frac{2 \pi}{365}$ ( $\mathrm{t}$ : Julian Day), $C$ is cloud amount, and $\alpha$ is albedo at the ocean surface (0.07). In actual calculation, $Q_{s}\left[=1.325 * Q_{s 0}-\right.$ 7.2697] is used as incident solar radiation from the

Fig. 9. Daily mean turbulent heat flux estimated from ECMWF data. Grid point: $45.0^{\circ} \mathrm{N} 142.5^{\circ} \mathrm{E}$. Shaded areas mean the observation periods for each year.

regression between the above formula and the 30 year averaged monthly mean data at the meteorological observatories of Hokkaido coast (Wakkanai, Kitami-esashi, Abashiri, Nemuro). The discrepancy between observation and the above formula may be due to a high albedo surface of snow cover.

The result of the daily turbulent heat flux is shown in Fig. 9. The averaged values for our observation period are estimated as $-25.1 \mathrm{~W} / \mathrm{m}^{2}$ in 1996 and $-18.2 \mathrm{~W} / \mathrm{m}^{2}$ in 1997 . These values are nearly the same as those estimated from our observational data. Figure 9 indicates that the turbulent heat flux is upward for almost all the period. The values of flux are eliminated by two thirds to a half compared with those without sea ice (not shown) and hence it is shown that the results obtained from our observational data almost hold for other periods.

The result of ice growth rate is shown in Fig. 10. The mean ice growth rates for our observation period are estimated as $0.13 \mathrm{~cm} /$ day in 1996 and $-0.09 \mathrm{~cm} /$ day in 1997 . Although somewhat underestimated compared with those obtained from our observation, it is shown in Fig. 10 that ice growth is as small in February and March of both years as that during the observation period. In January, the ice growth rate occasionally becomes somewhat larger due to lower air temperature. However, this region was not covered with sea ice yet at this time. Although relatively large fluxes are found in early March 1997 in Fig. 9 because of low cold out break 


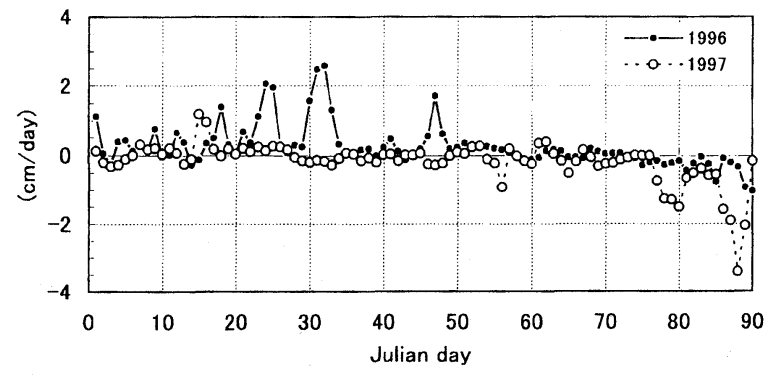

Fig. 10. Ice growth amount per day estimated from ECMWF data. Grid point: $45.0^{\circ} \mathrm{N} 142.5^{\circ} \mathrm{E}$ (See Fig. 1).

(air temperature $\sim-10^{\circ} \mathrm{C}$ ), ice growth is small due to increased solar radiation. Thus, it is confirmed that the result estimated from our observational data approximately holds good for the entire ice covering periods in this region.

\subsection{Diurnal cycle}

The brief characteristics of heat budget in this region was grasped above from the daily-averaged meteorological data. Here we further examine its diurnal cycle from averaged hourly meteorological data in 1997 (see Fig. 3). The method of calculation is the same as that for the case of Daily mean. Again, we assume that the left term of Eq. (1) $\left(\partial T_{S} / \partial t\right)$ is negligible.

First, we pay attention to thin nilas which initially forms over open water because the formation of new ice is particularly important for heat exchange with atmosphere and ocean structure. In calculation, surface albedo $(\alpha)$ is given as the following function of ice thickness $\left(H_{i}\right): \alpha=-2 * 10^{-6} H_{i}^{3}+4 * 10^{-4} H_{i}^{2}+$ $0.0205 H_{i}+0.0685$, which is derived from the observational data of Allison et al. (1993). Melting is supposed to occur when calculated surface temperature exceeds melting point $\left(0^{\circ} \mathrm{C}\right)$. In that case, the melting amount is calculated as $F Q /\left(\rho_{i} * L_{f}\right)$. Ice growth is predicted as a time evolution problem of 1 hour time step using the hourly data (Fig. 3).

Meteorological conditions were similar in 1996 and 1997 observation periods, and the 1997 data are used here. The result is shown in Fig. 11a. This figure shows that sea ice begins to form at the sunset, grows up to about $2 \mathrm{~cm}$ until early morning, and then melts away rapidly due to solar radiation. This maximum thickness is in agreement with the observed value during our cruise, and the diurnal cycle of estimated heat budget (not shown) is in good agreement with the detailed observational result over Lake Saroma by Ishikawa and Kobayashi (1984). Both results show that freezing occurs at night time when net radiation, sensible and latent heat fluxes are all outgoing sense. Thus it is indicated that solar radiation is a leading factor for ice growth in this region. This fact is also clearly shown
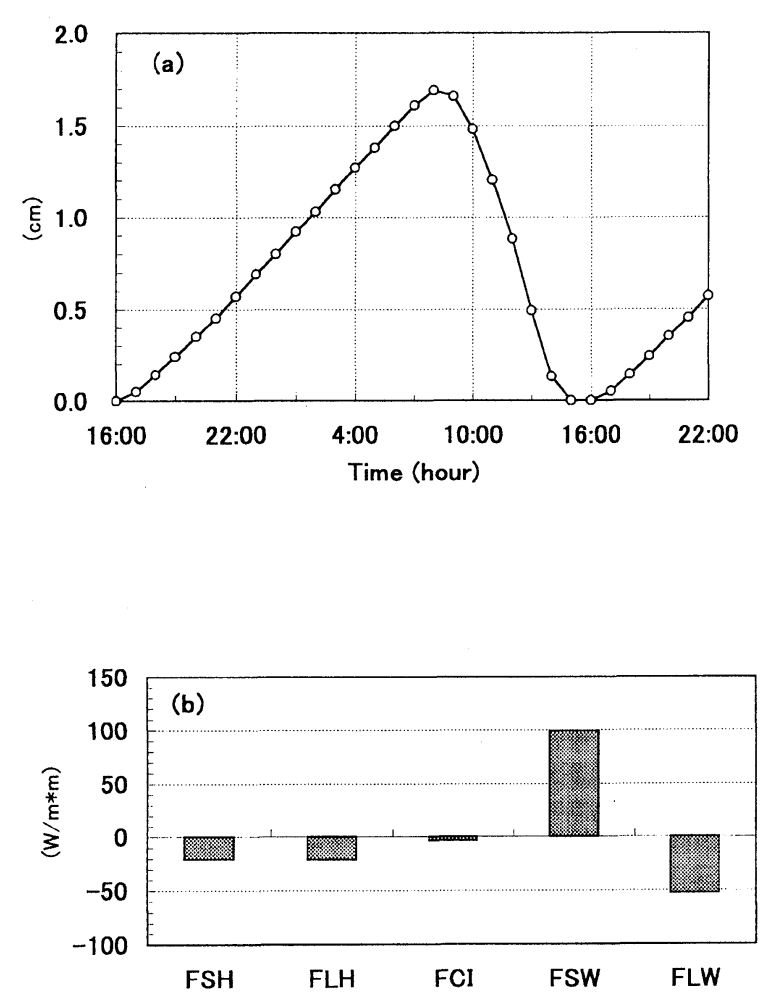

Fig. 11. Results of heat budget for open water, calculated from diurnal variation of meteorological data; (a) ice thickness and (b) daily averaged heat budget.

by the heat budget components in Fig. 11b, where the incident solar radiation is particularly prominent. This result shows that sea ice can hardly develop from open water on average.

Next we examine heat budget over the entire area. The method of calculation is the same as that used for daily mean calculation except that hourly data (Fig. 3) is used. We did not take the ice thickness change into account here because the treatment of the surface melting process is not easy, and the purpose here is to examine the effect of the meteorological diurnal cycle on heat budget. Here the heat budget is calculated with the same ice conditions. When the surface temperature $\left(T_{S}\right)$ is calculated as more than the melting point $(273.15 \mathrm{~K}), 273.15 \mathrm{~K}$ is substituted to $T_{S}$ and the residual heat flux $F Q$ $(=F S H+F L H+F C I+F S W+F L W)$ is calculated. $F Q$ is used to melt ice or snow.

The result is presented in Figs. 12a-c. It is shown from Fig. $12 \mathrm{a}$ that the emitted long wave radiation is balanced by the sensible heat flux and conductive heat flux at night, resulting in ice growth rate of $1.2 \mathrm{~cm} /$ day. It is noticeable that the turbulent heat flux is downward at night. On the other hand, Fig. 12b shows that the solar radiation is predominant and causes the surface melting at daytime. When averaged during one day, the effect of solar radiation remains prominent (see Fig. 12c), so that 

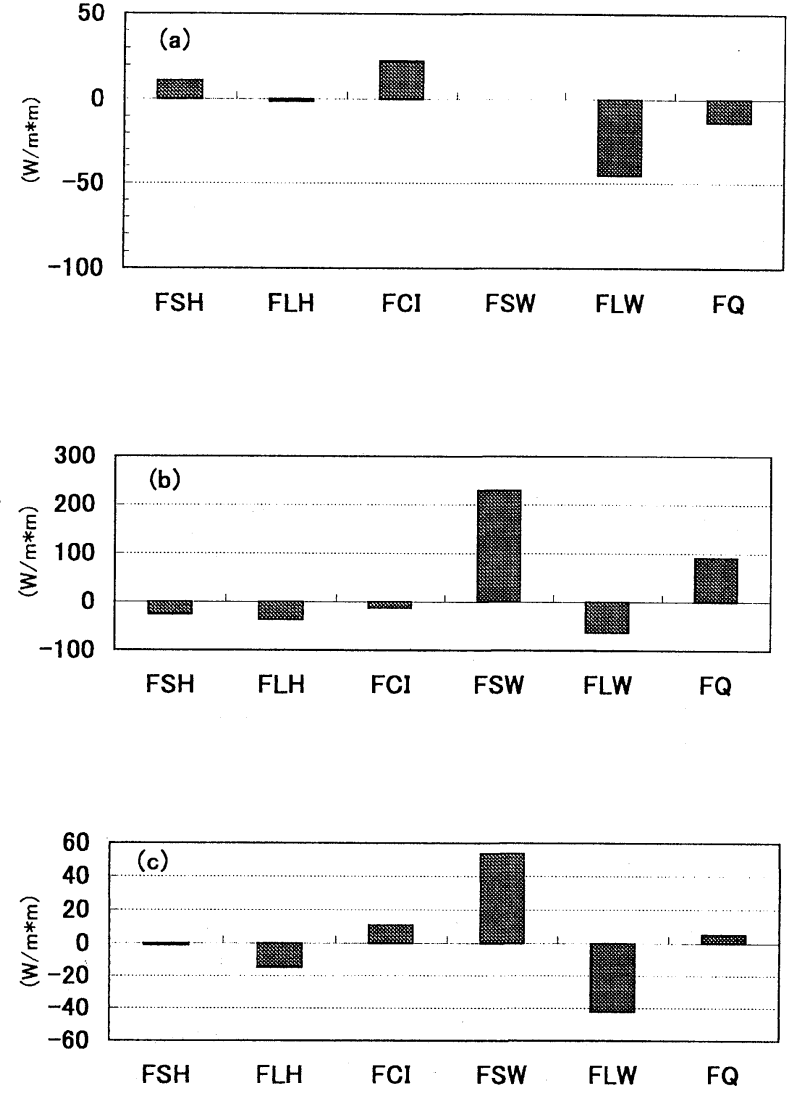

Fig. 12. Diurnal change of heat budget over the entire sea ice area, calculated from 1997 averaged hourly data. (a) at nighttime (0 hour) (b) at daytime (noon) and (c) daily mean.

ice growth rate becomes small $(0.4 \mathrm{~cm} /$ day $)$ and sea ice area functions as the heating source on average. The daily averaged profile (Fig. 12c) is almost same as Fig. 6b.

\section{Summary and discussion}

In order to examine the thermodynamical characteristics of sea ice area in the southern region of the Okhotsk Sea, we estimated the heat budget and the ice growth rate using the one-dimensional thermodynamical model on the basis of our ice and meteorological observation. The results are summarized as follows: (1) that the averaged ice growth rate is limited to below $1 \mathrm{~cm} /$ day, (2) that sea ice area reduces the turbulent heat flux over open water about by half, (3) that more than half of the total turbulent heat flux comes from open water and nilas area, and (4) that surface melting can occur at daytime due to solar radiation. It is shown through the analysis of ECMWF grid data that these results almost hold good through winter.

We examine errors which may be included in this method of estimation. Here, the $95 \%$ confidence interval of sea ice albedo $( \pm 0.03)$ is used as the estimation error because solar radiation flux is the leading factor in this region. Besides this factor, the errors caused by the estimation of snow cover depth and incoming long wave radiation are also considered. As for snow depth, we examined the cases in which snow depth $\left(H_{s}\right)$ is $1 / 4$ and $1 / 6$ of ice thickness $\left(H_{i}\right)$. The result is that the averaged ice growth rates for $H_{s}=H_{i} * 1 / 6$ are 0.51 and $0.27 \mathrm{~cm} /$ day in 1996 and 1997, respectively, and those for $H_{s}=H_{i} * 1 / 4$ are 0.45 and 0.23 in 1996 and 1997, respectively. The difference of the results seems small. Regarding incoming long wave radiation, we used the formula derived by Maykut and Church (1973), in which the difference between observation and prediction was estimated as $9 \%$. In our calculation, $9 \%$ decrease of incoming long wave radiation causes about $0.3 \mathrm{~cm} /$ day increase of ice growth, but does not alter the result significantly. Thus the sensitivity to these factors is small and our result essentially holds good.

In the first result, the actual ice growth rate would be further lower if ocean heat flux was included in this calculation. Ishikawa and Kobayashi (1984) estimated the ocean heat flux in Lake Saroma (salinity is $31 \mathrm{psu}$ ) in early February as 10 to $30 \mathrm{~W} / \mathrm{m}^{2}$. Wettlaufer (1991) estimated the ice-ocean heat flux in the Fram Strait in a fall season as 0 to $37 \mathrm{~W} / \mathrm{m}^{2}$. If these values are applied to our area, ocean heat flux is balanced by the estimated conductive heat flux and ice growth becomes substantially negligible.

The second result suggests that the northwesterly cold air is gradually transformed over this sea ice area through turbulent heat flux exchange. This is a different feature from that of the polar regions where thick ice $(\geq 1 \mathrm{~m})$ is predominant. From the analysis of heat flux over individual ice thickness, it was shown that thinner ice thickness is responsible for this result. This result is in contradiction to that of Okubo and Mannoji (1994). They showed using the JMA operational model that the sensible heat flux is downward over sea ice extent. We consider that this discrepancy is attributed to the treatment of sea ice area in their model, in which ice concentration is assumed to be 1.0.

On the other hand, the third result is similar to that of the polar regions in that thin ice area has an important role in exchanging heat between ocean and atmosphere. However, the estimated value $\left(40 \sim 60 \mathrm{~W} / \mathrm{m}^{2}\right)$ is much smaller than that over lead in winter in the polar regions (e.g. $120 \mathrm{~W} / \mathrm{m}^{2}$ (Allison et al. 1982), $130 \mathrm{~W} / \mathrm{m}^{2}$ (Ruffieux et al. 1995), $189 \mathrm{~W} / \mathrm{m}^{2}$ (Weller 1980), $115 \mathrm{~W} / \mathrm{m}^{2}$ (sensible heat flux; Walter et al. 1995). This much smaller value is considered to be due to relatively higher air temperature than in the polar regions. Thus the heat exchange over thin ice area seems not so drastic as in the polar regions. 
The fourth result may be one of the characteristics of sea-ice region at a relatively low latitude. Some evidences of this result could be found in ice samples. Figure 5 shows that although ice salinity certainly has a negative correlation with ice thickness, yet the values are smaller by about 3 psu than those of the first-year ice in the polar regions and rather closer to those of the multi-year ice (refer to Cox and Weeks 1974). Generally, the desalinization from first-year ice to multi-year ice is believed to occur mainly due to the percolation of the surface meltwater into sea ice in summer (Weeks and Ackley 1986). In our case, the heat budget calculation shows that surface melting possibly occurs at daytime. It is likely that this surface melted water at daytime lowered ice salinity as in the case of multi-year ice. This is also suggested by ice salinity structure. Many samples showed the trend that salinity increases with depth, which is similar to that of multi-year ice. Furthermore, it is suggested from Fig. 11 that less saline water can be produced at the sea surface due to the iteration of ice formation and melting. Actually, in some nilas samples we could find the ice crystal structure that may suggest this phenomenon. They had almost vertical c-axes in all the layer (about $1 \mathrm{~cm}$ thickness). This structure is similar to that of pure ice and supports our calculation.

Since in-situ observation by one vessel has limitations, we focused on discussing the temporally and spatially averaged characteristics of heat budget. It is desirable that these results will be examined by more detailed observation in the future.

\section{Acknowledgments}

We are sincerely grateful to the crew of $P / V$ $S O Y A$ of the Japan Coast Guard and the colleagues of ILTS for their kind cooperation throughout the cruise. We are also indebted to N. Iwasaka of Tokyo University of Mercantile Marine for his offering of the pyranometers. Thanks are extended to H. Shimoda of Ship Research Institute, Ministry of Transport, for his technical support of the observation and analysis of video monitoring. Useful discussions with K.I. Ohshima, Y. Fukamachi, J. Ukita, M. Ikeda, T. Yamanouchi, K. Yamazaki and K. Takeuchi are also acknowledged. This study was supported partly by a special fund, Center of Excellence (COE), for scientific research and partly by the Grant-in-Aid for Scientific Research on Priority Areas (Nos. 08241201 and 09227201), from the Ministry of Education, Science, Sports and Culture of Japan.

\section{References}

Allison, I., C.M. Tivendale, G.J. Akerman, J.M. Tann and R.H. Wills, 1982: Seasonal variations in the surface energy exchanges over Antarctic sea ice and coastal waters. Ann. Glaciol., 3, 12-16.

$\longrightarrow$, R.E. Brandt and S.G. Warren, 1993: East Antarctic sea ice: albedo, thickness distribution, and snow cover. J. Geophys. Res., 98, 12417-12429.

Andreas, E.L. and A.P. Makshtas, 1985: Energy exchange over Antarctic sea ice in the spring. J. Geophys. Res., 90, 7199-7212.

Aota, M., K. Shirasawa and T. Takatsuka, 1989: Measurements of an atmospheric boundary layer around the air-sea-ice observation tower: 1989 winter experiments. Low Temp. Sci., Ser., A48, 79-89. (in Japanese with English summary)

Chen, S.-J., Y.-H. Kuo, P.-Z. Zhang and Q.-F. Bai, 1991: Synoptic climatology of cyclogenesis over east Asia, 1958-1987. Mon. Wea. Rev., 119, 1407-1418.

Cox, G.F.N. and W.F. Weeks, 1974: Salinity variations in sea ice. J. Glaciol., 13, 109-120.

Grenfell, T.C. and G.A. Maykut, 1977: The optical properties of ice and snow in the Arctic Basin. $J$. Glaciol., 18, 445-463.

Gyakum, J.R., J.R. Anderson, R.H. Grumm and E.L. Gruner, 1989: North Pacific cold-season surface cyclone activity: 1975-1983. Mon. Wea. Rev., 117, 1141-1155.

Honda, M., K. Yamazaki, Y. Tachibana and K. Takeuchi, 1996: Influence of Okhotsk sea-ice extent on atmospheric circulation. Geophys. Res. Let., 23, 3595-3598.

Ishikawa, N. and S. Kobayashi, 1984: Experimental studies of heat budget of very thin sea ice. Seppyo, 46, 109-119 (in Japanese).

Kim, Y.-S., 1992: Estimate of heat transport across the sea surface near Japan with bulk methods. D. Sci., Univ. of Tokyo, 124pp.

Maykut, G.A., 1978: Energy exchange over young sea ice in the central Arctic. J. Geophys. Res., 83, 36463658 .

, 1982: Large-scale heat exchange and ice production in the Central Arctic. J. Geophys. Res., 87, 7971-7984.

and P.E. Church, 1973: Radiation Climate of Barrow, Alaska, 1962-66. J. Appl. Meteor., 12, 620680.

Mellor, M., 1977: Engineering properties of snow. $J$. Glaciol., 19, 15-66.

Nakamura, H., T. Toyota and M. Ohbayashi, 1986: Geographical distribution of the ratio of lengths of warm fronts to cold fronts in the northern hemisphere during 1978-1979 winter. J. Meteor. Soc. Japan, 64, 519-529.

Okubo, H. and N. Mannoji, 1994: The influence of the sea ice distribution on the surface wind forecast by Japan Spectral Model. Tenki, 41, 847-851 (in Japanese).

Ono, N., 1967: Specific heat and heat of fusion of sea ice. Physics of snow and ice, International conference on low temperature science, proceeding, Vol. 1, edited by H. Oura, $599-610$.

Overland, J.E. and C.H. Pease, 1982: Cyclone Climatology of the Bering Sea and its relation to sea ice extent. Mon. Wea. Rev., 110, 5-13. 
Persson, P.O.G., D. Ruffieux and C.W. Fairall, 1997: Recalculations of pack ice and lead surface energy budgets during the Arctic Leads Experiment (LEADEX) 1992. J. Geophys. Res., 102, 2508525089.

Ruffieux, D., P.O.G. Persson, C.W. Fairall and D.E. Wolfe, 1995: Ice pack and lead surface energy budgets during LEADEX 1992. J. Geophys. Res., 100, 4593-4612.

Sasaki, H. and S. Deguchi, 1988: Numerical experiments of the convergent band off the western coast of Hokkaido in winter. Tenki, 35, 723-729 (in Japanese).

Tachibana, Y., M. Honda and K. Takeuchi, 1996: The abrupt decrease of the sea ice over the southern part of the Sea of Okhotsk in 1989 and its relation to the recent weakening of the Aleutian low. J. Meteor. Soc. Japan, 74, 579-584.

Thorndike, A.S., D.A. Rothrock, G.A. Maykut and R. Colony, 1975: The thickness distribution of sea ice. J. Geophys. Res., 80, 4501-4513.

Toyota, T., J. Ukita, K.I. Ohshima, M. Wakatsuchi and K. Muramoto, 1999: A measurement of sea ice albedo over the southwestern Okhotsk Sea. J. Meteor. Soc. Japan, 77, 117-133.

Untersteiner, N., 1961: On the mass and heat budget of arctic sea ice. Arch. Met. Geophys. Bioklim.,
A(12): 151-182.

Walsh, J.E. and C.M. Johnson, 1979: An analysis of Arctic sea ice fluctuation, 1953-77. J. Phys. Oceanogr., 9, 580-591.

Walter, B.A., J.E. Overland and P. Turet, 1995: A comparison of satellite-derived and aircraft-measured regional surface sensible heat fluxes over the Beaufort Sea. J. Geophys. Res., 100, 4585-4591.

Watanabe, T. and M. Wakatsuchi, 1998: Formation of 26.8-26.9 $\sigma_{\theta}$ water in the Kuril Basin of the Sea of Okhotsk as a possible origin of North Pacific Intermediate Water. J. Geophys. Res., 103, 2849-2865.

Weeks W.F. and S.F. Ackley, 1986: The growth, structure and properties of sea ice. 'The geophysics of sea ice', edited by N. Untersteiner, 164pp.

Weller, G., 1980: Spatial and temporal variations in the south polar surface energy balance. Mon. Wea. Rev., 108, 2006-2014.

Wettlaufer, J.S., 1991: Heat flux at the ice-ocean interface. J. Geophys. Res., 96, 7215-7236.

World Meteorological Organization (WMO), 1970: Sea Ice Nomenclature, Terminology, Codes and Illustrated Glossary, WMO/OMM/BMO 259, TP 145 , Secr. World Meteorol. Organ., Geneva, Switzerland.

Yen, Y.C., 1981: Review of thermal properties of snow, ice, and sea ice. CRREL Rep., 81-10, 27pp.

\section{オホーツク海南部の海水域における熱収支の見積もり \\ 豊田威信・河村俊行・若土正暁 \\ (北海道大学低温科学研究所)}

1996 年と 1997 年の 2 月上旬に行われた気象、海水の現場観測を基に、オホーツク海南部の海水域にお ける海水域表面の熱収支を見積もった。計算に必要となる海水密接度、水厚分布はビデオ観測から定量的 に求めた。熱フラックスの計算は鉛直一次元熱力学モデルを用いて氷厚別に行い、領域全体の熱フラック スは各水厚の面積の重みをかけて足し合わせて求めた。その結果、(1) 比較的薄い海水が多いため、乱流 フラックスは上向きであり、海水域が乱流フラックスとして大気に熱を与えていること、(2) 領域全体の 乱流フラックスに対して開水面と薄水域が大きく寄与していること、(3) 平均海水成長量は $1 \mathrm{~cm} /$ day 以 下であり、熱力学的な成長は限られていること、などが分かった。(1) と (3) は比較的低緯度に位置するこ の海域の特徵と考えられ、(2)は比較的厚い海水が卓越する極域海水域における特徵と同様である。また、 計算結果から、日中は短波放射により表面融解が生じていることが示唆された。現場の海氷サンプルの塩 分は極域一年水よりも約 3 パーミル低く、むしろ多年水に近い值を示した。多年水は主として夏期の表面 融解により低塩分化することが知られており、同様の表面融解が 2 月のオホーツク海南部でも生じている と考えられる。 